\title{
The Level Assessment of Extracellular Nucleic Acids in the Blood of Pregnant Women with Chronic Hypertension with Superimposed Preeclampsia
}

Dinara Omertayeva ${ }^{1 *}$, Larissa Muravlyova ${ }^{1}$, Olga Ponomaryova ${ }^{1}$, Vilen Molotov-Luchanskyi ${ }^{2}$, Ryszhan Bakirova ${ }^{2}$, Dmitryi Klyuev ${ }^{1}$, Miras Mugazov ${ }^{3}$

${ }^{1}$ Department of Fundamental Medicine, National Join-stock Company Karaganda Medical University, Kazakhstan; ${ }^{2}$ Department of Therapy, National Join-stock Company Karaganda Medical University, Kazakhstan; ${ }^{3}$ Department of Surgical Diseases, National Join-stock Company Karaganda Medical University, Kazakhstan

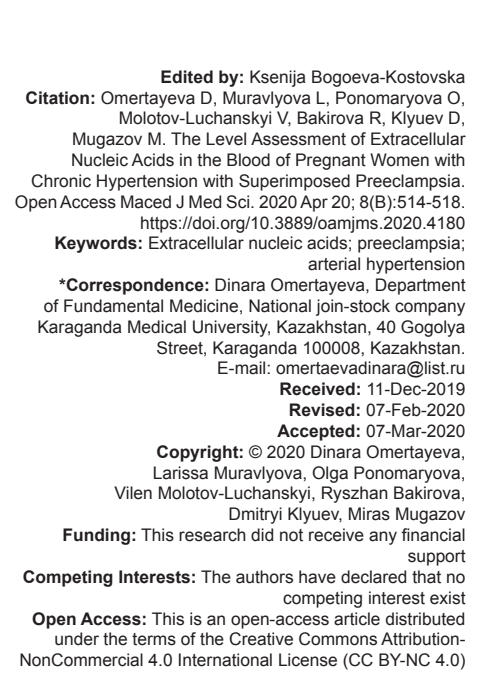

Abstract

BACKGROUND: Preeclampsia, chronic arterial hypertension is one of the causes of maternal and perinatal morbidity and mortality.

AIM: The aim of our study was to assess the level of extracellular nucleic acids in red blood cells and blood plasma in pregnant women with severe preeclampsia, severe chronic hypertension, and pregnant women with chronic hypertension with superimposed preeclampsia.

METHODS: A total of 107 pregnant women were examined who were hospitalized at the Regional Clinical Hospital and at the Regional Perinatal Center in Karaganda and 29 healthy non-pregnant women. Pregnant women were divided into four groups: 1 group - 32 pregnant with severe chronic hypertension, 2 group - 48 pregnant women with severe preeclampsia, 3 group - 35 women entered the group with chronic hypertension with superimposed preeclampsia, and group control -29 healthy non-pregnant women of child bearing age ( $4^{\text {th }}$ group - control).

RESULTS: The content of ecNA in the erythrocytes of pregnant women with chronic hypertension with superimposed preeclampsia sharply increases relative to the control and comparison groups; in pregnant women with severe hypertension and severe preeclampsia, the level of ecNA is moderately higher relative to the control, but lower than in the main group.

CONCLUSION: Our data indicate significant changes in the level of ecNA in pregnant women with various types of hypertension and require further research, but now, changes in the concentration of ecNA can be considered as one of the links in the pathogenesis of preeclampsia.

\section{Introduction}

Various types of hypertension are occurred during pregnancy: Preeclampsia, chronic arterial hypertension, chronic hypertension with superimposed preeclampsia, and gestational hypertension [1], [2], [3]. Preeclampsia and chronic arterial hypertension are one of the reasons of maternal and perinatal morbidity and mortality [2], [4], [5], [6]. The prevalence rate of preeclampsia in the world is $2.7-8.2 \%$ [3], [4], [5], [6]. Percentage of maternal mortality, caused by diseases of circulatory system, is 29.8 [7]. Preventive activities have low efficiency, and screening tools are not always specific, treatment is aimed at eliminating obvious clinical manifestations. The only effective treatment of these conditions is delivery [8], [9]. Thus, this complication of pregnancy remains a serious problem for doctors.

Preeclampsia is a heterogeneous disorder, triggered by several different underlying mechanisms.
There are more than 30 theories of the development of preeclampsia [8], [9], [10], [11]. One of the leading is the theory of endothelial dysfunction [12] and placental theory [9]. Violation of trophoblast invasion leads to decrease in oxygenation and, accordingly, to the formation of oxidative stress. Microvasculature's damage in organs and tissues leads to oxidative stress and accumulation of reactive oxygen species (ROS). The result of lipid and protein peroxidation, activation of membrane phospholipases, mechanical (osmotic) stretching, and adsorption of foreign proteins are destruction of cells' structural and functional properties [8], [9], [11].

At present, extracellular nucleic acids (ecNA) have a great interest [13], [14], [15], [16].

Extracellular nucleic acids can exist in free form or can be absorbed on blood cells or as a part of vesicles [15], [16], [17], [18]. Usually, the amount of circulating DNA is very low in healthy people. The growth of circulating DNA is observed in patients with 
certain types of cancer process [19], [20], [21], [22], in pregnant women [23], [24].

Extracellular DNA in the blood plasma of pregnant women is used as an additional criterion for prenatal diagnosis of determining the Rh-factor, the sex of the fetus, and determining the risk of premature birth [24], [25], [26]. A single study in the literature reports that an increasing of extracellular DNA in the first trimester of pregnancy is connected with the development of preeclampsia [27]. However, there are no data on the state of ecNA in the second and third trimester in pregnant women with hypertensive disorders.

One of the reasons of the growth of extracellular DNA is considered of violation of the invasion of chorionic villi. The literature describes data on the placental nucleic acids [27], [28], [29], [30], [31]. A higher concentration of extracellular placental DNA is associated with pregnancy complications and a higher risk of fetal rejection. It is still not clear whether higher concentrations of extracellular nucleic acids in maternal circulation cause or result from various complications.

A hypothesis has been proposed that oxidative damage of DNA occurs under conditions of oxidative stress. Fragments of oxidized DNA are released from the nuclei of cells and act as a stress signal. Oxidized DNA can be reason of ROS's formation, which triggers an adaptive response, including changes in gene expression of antioxidant defense and detoxification enzymes and the formation of stress actin filaments [32].

Extracellular RNA can be released from cells both by the formation of vesicles and in combination with proteins that protect them from the effects of endonucleases. It is believed that RNA protected by vesicles or proteins can perform the function of intercellular communicators [33].

The literature describes single study of ecNA in pregnant women with preeclampsia in pregnancy or with arterial hypertension [29]; however, there are no studies regarding to ecNA content in pregnant women suffering from chronic hypertension with superimposed preeclampsia. To date, there is a high incidence of such a combined pathology, which is clinically characterized by increased blood pressure, the appearance of proteinuria $(0.3 \mathrm{~g} / \mathrm{l}$ or more) in urinalysis, the possible development of complications such as intrauterine growth retardation, placental abruption, cerebrovascular accident, more often hemorrhagic type, and other complications of preeclampsia and hypertension [1], [2], [9]. Thus, the clinical and pathogenetic significance of extracellular nucleic acids in the mother's blood with chronic hypertension with superimposed preeclampsia remains poorly studied, as well as their role in the pathogenesis of this pathology.

\section{The purpose of the study}

In this regard, the aim of our study was to assess the level of extracellular nucleic acids in red blood cells and blood plasma in pregnant women with severe preeclampsia, severe chronic hypertension, and pregnant women suffered from chronic hypertension with superimposed preeclampsia.

\section{Materials and Methods}

A total of 107 pregnant women were hospitalized at the Regional Clinical Hospital and at the Regional Perinatal Center in Karaganda and 29 healthy non-pregnant women. The criterion for the inclusion of pregnant women in the study was the informed consent of the woman to participate in the study and gestational age between 20 and 42 weeks. The age of patients ranged from 18 to 48 years (mean age -28.66 years). The age of pregnant women are younger than 25 years$15.3 \%, 26-30$ years $-38.1 \%, 36-40$ years $-60.6 \%$, $41-48$ years $-7.2 \%$. It was found that the prevalence of hypertension is high in the groups of patients 26-30 and 36-40 years old. The exclusion criteria were cancer diseases, HIV infection, tuberculosis, concomitant severe somatic pathology, obesity, mental illness, and drug addiction. The study design was approved by the ethics committee of the Karaganda Medical University (No. 33, 03/01/2018). Pregnant women were divided into three groups and group control:

- $\quad$ Group 1 - 32 pregnant with severe chronic hypertension

- $\quad$ Group 2 - 48 pregnant women with severe preeclampsia

- $\quad$ Group 3 - 35 women entered the group with chronic hypertension with superimposed preeclampsia

- Group control - 29 healthy non-pregnant women of childbearing age (Group 4 - control).

We have taken non-pregnant women as a control because the literature data report that there are no significant differences in the level of extracellular nucleic acids in the blood of healthy pregnant and nonpregnant women. Hence, in the work of Ershova et al., there were no significant differences in the content of extracellular (cell free) nucleic acids (both average and median) in the blood of healthy pregnant women and non-pregnant women [34].

The diagnosis of severe preeclampsia, severe arterial hypertension, and chronic hypertension with superimposed preeclampsia has made on the basis of the classification proposed by the protocol of diagnosis and treatment of the Ministry of Health of the Republic of Kazakhstan "Arterial hypertension in pregnant women" No. 36 dated December 27, 2017 (based on ICD-10), 
with a systolic blood pressure (SBP) $\geq 160 \mathrm{mmHg}$ and/or diastolic blood pressure (DBP) $\geq 110 \mathrm{mmHg}$. Severe preeclampsia was diagnosed in pregnant women based on an increase in SBP $\geq 160 \mathrm{mmHg}$ and/ or DBP $\geq 110 \mathrm{mmHg}$ with proteinuria $0.3 \mathrm{~g} / \mathrm{l}$ and more in the single portion of urine or proteinuria in the daily urine $0.3 \mathrm{~g}$ and more. Pregnant women with HELLP syndrome and eclampsia are excluded from the study.

Blood was the material of the study. It was stabilized by heparin. A blood test has been performed no later than an hour after blood sampling. The acid-soluble fraction (ASF) of nucleic acid precursors, extracellular RNA, and DNA in plasma was evaluated by the method of Markusheva et al. [33]. The unit of measurement is $\mu \mathrm{g} / \mathrm{ml}$. The principle of quantitative determination of ASF, RNA, and DNA consisted of the extraction of nucleic acids after hydrolysis carried out at various temperatures in a water bath, followed by centrifugation for $15 \mathrm{~min}$ at $3000 \mathrm{r} / \mathrm{pm}$ and spectrophotometry of ASF, RNA, and DNA hydrolysates [33].

\section{Results}

The results have processed by statistical methods: Descriptive statistics (median, upper, lower quartile, and reliability were determined using dispersion analysis - nonparametric Kruskal-Wallis test, pairwise non-parametric Mann-Whitney U-test). The results are presented in Tables 1 and 2.

From the data, Table 1 follows that the content of ecNA in plasma and red blood cells has a multidirectional change in indicators.

The highest ecNA values in the blood erythrocytes were found in pregnant women of the third (main) group: A significant increase in ASF by 8 times, RNA by 5 times, and DNA by 4 times relative to the control group at $p<0.013$ (by median). In Groups 1 and 2 of pregnant women, there was a trend to increase the level of ecNA relative to control. A significant increase in the level of ecNA in the main group relative to comparison groups by more than 3 times is also determined.

In plasma, a significant increase in ecNA was also observed in the main group of pregnant women with respect to the control: An increase in ASF, RNA, and DNA by 3 times relative to the control group with $p<0.013$ (by median). The ecNA's level of the comparison groups was also higher relative to the control by 2 times. The level of RNA and DNA in the main group was 1.5-2.0 times higher relative to the comparison groups (by median), while the ASF level was the highest in the blood plasma of Group 2 relative to the control. There was a tendency toward an increase in plasma levels of RNA and DNA of pregnant women with severe preeclampsia relative to pregnant women with severe chronic hypertension.

As a result of the study, it was found that the content of ecNA in pregnant women with various types of hypertension significantly increased relative to the control. Thus, the content of ecNA in the erythrocytes of pregnant women with chronic hypertension with superimposed preeclampsia sharply increases relative to the control and comparison groups. The level of ecNA in pregnant women with severe chronic hypertension and severe preeclampsia is moderately higher relative to the control, but lower than in the main group. A similar picture is also observed in the blood plasma; however, the severity of differences relative to control is lower than in the red blood cells, and the dynamic of plasma ASF in the main group differs significantly compared to comparison groups. Thus, as a result of the study, ecNA of pregnant women with chronic hypertension with superimposed preeclampsia is more associated with red blood cells. The binding of ecNA to erythrocytes leads to destabilization of erythrocyte membranes, loss of elasticity of red blood cell, and resistance to shear stress decreases. Such red blood cells die prematurely in the bloodstream, releasing procoagulant coagulation factors, and also contribute to the development of oxidative stress. In addition, ecNA binding to erythrocytes affects to the transport function of red cell membranes, thereby leading to a change of the osmotic resistance of red blood cells, as well as

Table 1: Extracellular nucleic acids in the red blood cells

\begin{tabular}{lll}
\hline Groups & $\begin{array}{l}\text { ASF in erythrocytes } \\
\text { Median Q25 Q75 }\end{array}$ & $\begin{array}{l}\text { RNA in erythrocytes Median } \\
\text { Q25 Q75 }\end{array}$ \\
\hline 1 Severe arterial hypertension (comparison group) & $0.0063^{*}(0.0228 ; 0.0036)$ & $0.0093^{*}(0.0264 ; 0.0035)$ \\
2 Severe preeclampsia (comparison group) & $0.0065^{*}(0.0193 ; 0.0049)$ & $0.0049(0.0171 ; 0.0023)$ \\
3 Chronic hypertension with superimposed preeclampsia (the main group) & $0.0257^{*}(0.0369 ; 0.0217)$ & $0.0216^{*} \#(0.0274 ; 0.0100)$ \\
Control & $0.0032(0.0043 ; 0.0016)$ & $0.0038(0.0059 ; 0.0012)$ \\
\hline${ }^{*}$ Significant differences between 1, 2, and 3 of ASF and the control P<0.013. *Significant differences between Groups 1 and 3 of RNA and the control. * *ignificant difference between Groups 1, 2, and 3 of DNA and the & $0.0234^{*}(0.0450 ; 0.0175)$ \\
control. \#Significantly differences between Groups 2 and 3 of RNA. "Significant difference between 1 group of DNA and 3 group of DNA. ASF: Acid-soluble fraction.
\end{tabular}

Table 2: Extracellular nucleic acids in the plasma

\begin{tabular}{|c|c|c|c|}
\hline Groups & ASF in plasma Median (Q25 Q75) & RNA in plasma Median (Q25, Q75) & DNA in plasma Median (Q25, Q75) \\
\hline 1 Severe arterial hypertension (comparison group) & $0.0172^{\star}(0.0234 ; 0.0128)$ & $0.0053^{\%}(0.0063 ; 0.0037)$ & $0.0041(0.0086 ; 0.0023)$ \\
\hline 2 Severe preeclampsia (comparison group) & $0.0240 *(0.0347 ; 0.0158)$ & $0.0071 *(0.0143 ; 0.0057)$ & $0.0072^{\star}(0.0217 ; 0.0053)$ \\
\hline 3 Chronic hypertension with superimposed preeclampsia (main group) & $0.0190 *(0.0500 ; 0.0136)$ & $0.0118^{* 8}(0.0247 ; 0.0057)$ & $0.0107^{* \wedge}(0.0327 ; 0.0086)$ \\
\hline Control & $0.0116(0.0178 ; 0.0025)$ & $0.0043(0.0055 ; 0.0038)$ & $0.0047(0.0052 ; 0.0038)$ \\
\hline
\end{tabular}


inhibiting the transport of hemoglobin and subsequent complete gas exchange, which ultimately leads to hypoxia, oxidative stress. Furthermore, ecNA binding to erythrocytes can be transformed into microvesicles, the significance and function of which remains poorly understood to date [18].

Circulation of ecNA in plasma in a large quantity affects to the rheological properties of blood. More likely, long-circulating ecNA in plasma can activate the blood coagulation system, which leads to the chronic disseminated intravascular coagulation syndrome, which is one of the pathogenetic mechanisms of gestosis. It is still not clear whether higher concentrations of ecNA in maternal circulation cause or result from various complications. It can be assumed that a high level of ecNA in a group of pregnant women with such pathology as a chronic hypertension with superimposed preeclampsia is more likely to be associated with the potentiating effect of both nosologies on the target organs - kidneys, hemostasis system. It can be assumed that the level of ecNA in pregnant women with chronic hypertension with superimposed preeclampsia is probably due to the maternal part of ecNA; however, a number of studies need to be conducted to answer this question.

Clinical application of ecNA research demonstrates prospects for further studies of extracellular nucleic acids to determine their participation in the mechanisms of development and progression of kidney damage in pregnant women with chronic hypertension with superimposed preeclampsia. As a future perspective, the continuation of the study of the ecNA will probably allow it to be used as a target treatment. Extracellular RNA activates contact phase of coagulation. Extracellular RNA's growth indicates enhanced coagulation and supports mechanisms of gestosis. Thus, it can be used for determining of disease progression; however, further research is needed.

\section{Conclusion}

Thus, our data indicate significant changes in the level of ecNA in pregnant women with various types of hypertension and require further research; however, changes in the concentration of ecNA can be considered as one of the links in the pathogenesis of preeclampsia. In addition, it is necessary to study ecNA and simultaneously study extracellular vesicles, which may also contain ecNA (platelet's, leukocyte's, erythrocyte's vesicles, as well as endothelial vesicles) [18]. At present, the only treatment of preeclampsia, as well as severe chronic hypertension, is delivery. Premature delivery often leads to high neonatal mortality and morbidity. Thus, it is necessary to continue the study of ecNA, extracellular vesicles, and their complex interactions to further understand the initiation and progression of a hypertensive state of pregnancy. This result shows perspectives of ecNA's profound investigation to determine their role in gestosis' development.

\section{References}

1. Magee LA, Helewa M, Rey E. Diagnosis, evaluation, and management of the hypertensive disorders of pregnancy. J Obstet Gynaecol Can. 2008;30 Suppl 3:S1-2.

PMid:18817592

2. Federal Clinical Guidelines. Diagnosis and Treatment of Arteria Hypertension in Pregnant Women. Mirko: Federal Clinical Guidelines; 2014.

3. ACOG Committee on Practice Bulletins--Obstetrics. ACOG Practice Bulletin. Diagnosis and management of preeclampsia and eclampsia. Number 33, January 2002. Obstet Gynecol. 2002;99(1):159-67. https://doi.org/10.1016/ s0029-7844(01)01747-1

PMid:16175681

4. EngenderHealth. Balancing the Scales: Expanding Treatment for Pregnant Women with Life-threatening Hypertensive Conditions in Developing Countries; a Report on Barriers and Solutions to Treat Preeclampsia and Eclampsia. New York: EngenderHealth; 2007.

5. Venckovskij BM, Zaporozhan VN, Senchuk AY, Skachko BG Gestosis: Guide fordoctors-M. Med Inform Agents. 2005;1:312.

6. NICE. Hypertension in Pregnancy, Clinical Guideline. Israel: NICE; 2010.

7. Norwitz ER, Repke JT. NHLBI National High Blood Pressure Education Program. United States: ACOG; 2009

8. Dekker GA, Sibai BM. Etiology and pathogenesis of preclampsia: Current concepts. Am J Obstet Gynecol. 1998;179(5):1359. PMid:9822529

9. Ajlamazyan EK. Gestosis: Theory and Practice. M. Russia: Medpress-Inform; 2008.

10. Chesley LC, Cooper DW. Genetics of hypertension in pregnancy: Possible single gene control in eclampsia and preclampsia in the descendants of eclamptic women. $\mathrm{Br} \mathrm{J}$ Obstetgynaecol. 1986;93(9):898-908. https://doi.org/10.1111/j.1471-0528.1986. tb08006.x

11. Wang A, Rana S, Karumanchi SA. Preeclampsia: The role of angiogenic factors in its pathogenesis. Physiology (Bethesda). 2009;24:147-58. https://doi.org/10.1152/physiol.00043.2008 PMid:19509125

12. Adu-Bonsaffoh K, Antwi A, Gyan B, Obed SA. Endothelia dysfunction in the pathogenesis of preeclampsia in Ghanaian women. BMC Physiol. 2017;17(1):5. https://doi.org/10.1186/ s12899-017-0029-4 PMid:28356151

13. Pinzani P, Salvianti F, Pazzagli M, Orlando C. Circulating nucleic acids in cancer and pregnancy. Methods. 2010;50(4):302-7. https://doi.org/10.1016/j.ymeth.2010.02.004 PMid:20146940

14. Mandel $P$, Metais $P$. Les acides nucléiques du plasma sanguin chez l'homme. C R Seances Soc Biol Fil. 1948;142(3-4):241-3. PMid:18875018

15. Leon SA, Shapiro B, Sklaroff DM, Yaros MJ. Free DNA in the serum of cancer patients and the effect of therapy. Cancer Res. 1977;37(3):646-50. 


\section{PMid:837366}

16. Swarup V, Rajeswar MR. Circulating (cell-free) nucleic acids--a promising, non-invasive tool for early detection of several human diseases. FEBS Lett. 2007;581(5):795-9.

PMid:17289032

17. Muravlyova L, Molotov-Luchanskyi V, Klyuyev D, Tankibayeva N, Koyikov V. Extracellular nucleic acids: Origin and function. Mod Probl Sci Educ. 2010;2:15-20.

18. Muravlyova L, Molotov-Luchanskyi V, Bakirova R Ponomaryova O, Omertayeva D. Red-blood cell-derivated microparticles and oxidative stress intermediates in erythrocytes of pregnant women with preeclampsia and hypertension. Free Radic Biol Med. 2019;139:S10-57. https://doi.org/10.1016/j. freeradbiomed.2015.07.129

19. Frattini M, Balestra D, Verderio P, Gallino G, Leo E, Sozzi G, et al. Reproducibility of a semiquantitative measurement of circulating DNA in plasma from neoplastic patients. J Clin Oncol. 2005;23(13):3163-4. https://doi.org/10.1200/jco.2005.05.430 PMid:15860889

20. Gal S, Fidler C, Lo YM, Taylor M, Han C, Moore J, et al. Quantitation of circulating DNA in the serum of breast cancer patients by real-time PCR. Br J Cancer. 2004;90:1211-5. PMid:15026803

21. Schwarzenbach $\mathrm{H}$, Pantel K, Kemper B, Beeger C, Otterbach F, Kimmig $\mathrm{R}$, et al. Comparative evaluation of cell-free tumor DNA in blood and disseminated tumor cells in bone marrow of patients with primary breast cancer. Breast Cancer Res. 2009;11(5):R71. https://doi.org/10.1186/bcr2404 PMid:19772563

22. Schwarzenbach H, Alix-Panabiures C, Mbller I, Letang N, Vendrell JP, Rebillard X, et al. Cell-free tumor DNA in blood plasma as a marker for circulating tumor cells in prostate cancer. Clin Cancer Res. 2009;15(3):1032-8.

PMid:19188176

23. Hahn S, Jackson LG, Kolla V, Mahyuddin AP, Choolani M. Noninvasive prenatal diagnosis of fetal aneuploidies and mendelian disorders: New innovative strategies. Expert Rev Mol Diagn. 2009;9(6):613-21.

PMid: 19732005

24. Hung EC, Chiu RW, Lo YM. Detection of circulating fetal nucleic acids: A review of methods and applications. J Clin Pathol. 2009;62:308-13.
25. Chan AK, Chiu RW, Lo D. Cell-free nucleic acids in plasma, serum and urine: A new tool in molecular diagnosis. Ann Clin Biochem. 2003;40(2):122-30.

26. Tsang JC, Lo YM. Circulating nucleic acids in plasma/serum. Pathology. 2007;39(2):197-207. PMid:17454749

28. Maron JL, Bianchi DW. Prenatal diagnosis using cell-free nucleic acids in maternal body fluids: A decade of progress. Am J Med Genet C Semin Med Genet. 2007;145C(1):5-17. PMid:17299735

29. Ng EK, Tsui NB, Lau TK, Leung TN, Chiu RW, Panesar NS, Lit LC, Chan KW, Lo YM. mRNA of placental origin is readily detectable in maternal plasma. Proc Natl Acad Sci U S A. 2003;100(8):4748-53.

PMid:12644709

27. Tsui NB, Chim SS, Chiu RW, Lau TK, Ng EK, Leung TN, et al. Systematic micro-array based identification of placental mRNA in maternal plasma: Towards non-invasive prenatal gene expression profiling. J Med Genet. 2004;41(6):461-97. PMid:15173234

30. Wong BC, Chiu RW, Tsui NB, Chan KC, Chan LW, Lau TK, et al. Circulating placental RNA in maternal plasma is associated with a preponderance of 5 mRNA fragments: Implications for noninvasive prenatal diagnosis and monitoring Clin Chem. 2005;51:1786-95.

31. Ermakov AV, Konkova MS, Kostyuk SV, Izevskaya VL, Baranova A, Veiko NN. Oxidized extracellular DNA as a stress signal in human cells. Oxid Med Cell Longev. 2013;2013:649747. PMid:23533696

32. Muravlyova L, Molotov-Luchanskyi V, Klyuyev D. Extracellular nucleic acids in the blood of patients with chronic renal failure. Int J Exp Educ. 2014;3(1):75-7.

33. Markusheva LI, Savina ME, Toguzov RT, Reshina VM. Nuclear chromatin proteins in evaluating the effectiveness of treatment of patients with psoriasis. Clin Lab Diagn. 2000;7:18-20.

34. Ershova E, Sergeeva V, Klimenko M, Avetisova K, Klimenko P, Kostyuk E, et al. Circulating cell-free DNA concentration and DNase I activity of peripheral blood plasma change in case of pregnancy with intrauterine growth restriction compared to normal pregnancy. Biomed Rep. 2017;7(4):319-24. https://doi. org/10.3892/br.2017.968

PMid:29085628 